\title{
OPTIMALISASI PEMBELAJARAN IPS DENGAN KUIS HOM PI PAH DI KELAS VIII SMP NEGERI 16 KOTA BOGOR
}

\author{
Gunarti Sukriyatun \\ Guru SMP Negeri 16 Kota Bogor \\ Email: sukriyatun30@yahoo.co.id
}

\begin{abstract}
Abstrak
Tujuan setiap pembelajaran adalah mencapai Ketuntasan Belajar Minimal (KKM) dan untuk terus meningkatkan kualitas pendidikan. Upaya yang dilakukan agar memperoleh hasil belajar yang maksimal, guru harus memiliki kemampuan memilih model pembelajaran yang sesuai dengan tingkat kesulitan pokok bahasan yang dipelajari. Guru dituntut untuk memilih model pembelajaran yang tepat seperti pada mata pelajaran Ilmu Pengetahuan Sosial yang konsepnya bersifat abstrak, maka akan lebih cocok jika menggunakan model pembelajaran yang sifatnya kolaboratif. Selain itu, Guru harus bisa memodifikasi metode pembelajaran dengan kegiatan yang lebih mengaktifkan peserta didik. Penelitian Tindakan Kelas ini dilaksanakan dalam 2 siklus. Siklus pertama membahas tema "Ketenagakerjaan", Data diperoleh dari hasil ulangan, dan penilaian kolaborator/pengamat. Siklus kedua dilaksanakan seperti pada siklus pertama dengan tema yang sama yaitu "Ketenagakerjaan" dengan refisi hasil refleksi siklus 1. Dari data hasil penelitian diperoleh kenaikan prestasi belajar dari KBM siklus 1 yaitu rata rata kelas 74,46. Hasil tersebut ada kenaikan nilai ratarata bila dibandingkan dengan pra siklus dengan perolehan nilai rata-ratanya sebesar 64,17 . Begitu pula nilai rata-rata yang diperoleh pada siklus ke 2, ada kenaikan nilai rata-rata dari siklus pertama yaitu menjadi 82,29. Sedangkan pada pengelolaan KBM siklus pertama Guru mendapat persentase skor total 82,50\% dengan kategori baik, meningkat di siklus 2 menjadi 98,33\% dengan kategori sangat baik. Berdasarkan data yang diperoleh dari hasil penelitian ini, membuktikan bahwa penggunaan metode kuis hom pi pah mampu mengoptimalkan pembelajaran sehingga meningkatkan prestasi belajar Peserta Didik.
\end{abstract}

Kata kunci : KKM, PTK, model pembelajaran, kuis Hom Pi Pah.

\section{PENDAHULUAN}

Mutu Pendidian di Indonesia masih sangat rendah dibandingkan dengan negara tetangga yang masih dalam kategori sama yaitu negara berkembang. Hal ini nampak dalam Kriteria Kelulusan yang ditetapkan oleh Pemerintah. Di tingkat Sekolah, Pesera Didik masih banyak yang mengejar nilai khusus hanya mata pelajaran yang di Ujian Nasionalkan dan mengesampingkan mata pelajaran yang lain. Demikian juga dengan mata pelajaran IPS.

Sering terjadi pada saat tatap muka, Peserta Didik meninggalkan kelasnya dengan berbagai alasan. Peserta Didik menganggap enteng mata pelajaran IPS dengan tidak segera menyelesaikan kegiatan mandiri lainnya. Pesera Didik lebih menyulai pola lama dalam belajar yaitu Datang, Duduk dan Diam. Sementara Guru sudah berupaya dengan berbagai cara, metode maupun model pembelajaran.

Pesera Didik sangat pasif dalam menjawab pertanyaan/masalah yang disampaikan Guru.Untuk mengatasi hal tersebut, Guru mencoba menggunakan berbagai kuis. Diantaranya adalah penggunaan kuis Hom Pi Pah agar Peserta Didik lebih termotifasi dalam mengikuti pembelajaran dan hasil yang diharapkan menjadi lebih optimal.Hal ini karena dengan kuis Hom pi pah, peserta didik menjadi lebih aktif dan saling berlomba untuk dapat lebih dulu menjawab pertanyaan dan mendapatkan nilai. 


\section{KAJIAN PUSTAKA}

Menurut teori Daya, belajar adalah kegiatan individu untuk melatih dayadaya yang ada pada dirinya. Teori didasari oleh asumsi bahwa otak manusia memiliki suatu potensi yang berupa daya ingat, daya pikir, daya untuk mengeksfresikan sesuatu, daya kreatif, dan daya-daya lainnya. Sedangkan Belajar dalam teori asumsi adalah melakukan resfon tertentu terhadap stimulus (rangsangan) yang datang atau muncul dari lingkungan sekitarnya. Hal ini didasari oleh asumsi bahwa setiap manusia mempunyai potensi untuk memberikan respon atau suatu stimulus yang datang dari lingkungannya. Unsur-unsur yang terdapat dalam situasi belajar sehingga peserta didik memahami sesuatu yang baru.

Menurut Oemar Hamalik (1999:36) bahwa belajar adalah suatu bentuk pertumbuhan atau perubahan dalam diri seseorang yang dinyatakan dalam cara cara bertingkah laku yang baru secara keseluruhan sebagai hasil pengalamannya sendiri dalam interaksi dengan lingkungannya.

Berdasarkan teori Gestalt, belajar dapat didefinisikan terhadap beberapa rumusan sebagai berikut:

a. Belajar adalah proses yang terjadi bila seseorang mendapat insting di dalam suatu keadaan yang problematic baru.

b. Belajar adalah proses akhir yang dilaksanakan melalui berbuat, mengadakan reaksi dan mengalami sesuatu yang memungkinkan terbentuknya pengetahuan, keterampilan dan sikap baru pada pihak belajar.

c. Belajar adalah proses interaksi antara berbagai potensi yang ada pada diri peserta didik dengan aneka potensi yang datang dari guru, peserta didik lainnya, fakta-fakta yang dikenalnya, konsep-konsep yang ditemukannya dan lingkungan hidup.

Belajar dipandang sebagai suatu proses, memiliki tahapan-tahapan yang harus dilaluinya. Tahapan-tahapan tersebut dikenal dengan sebutan fase-fase belajar. Robert M. Gagne mengungkapkan bahwa dalam belajar tersebut terdiri dari empat tahapan sebagai berikut:

a. Fase Apprehending atau fase pemahaman

b. Fase acqistion atau fase pemilikan

c. Fase Storage atau fase penyimpanan

d. Fase retrieval atau fase pengeluaran kembali.

Dalam hal ini Jerome Burner, menyatakan pendapatnya bahwa proses belajar tersebut terdiri dari fase sebagai berikut:

a. Fase penerimaan informasi

b. Fase transformasi

c. Fase evaluasi

Dengan diketahui dan dipahaminya teori dan fase-fase dalam belajar maka diharapkan seorang guru dalam melaksanakan kegiatan pembelajaran disesuaikan dengan kondisi dan tingkat psikologis peserta didik yang bersangkutan.

Pembelajaran berpusat kepada tujuan yang hendak dicapai berdasarkan perencanaan. Pembelajaran adalah proses yang terjadi yang membuat seseorang atau sejumlah orang yaitu peserta didik melakukan proses belajar sesuai dengan rencana pengajaran yang telah diprogramkan. Unsur kesengajaan melalui perencanaan oleh pihak guru merupakan ciri utama pembelajaran. Upaya pembelajaran yang berporos kepada pihak guru, dilaksanakan secara sistematis 
yaitu dilakukan dengan langkah langkah teratur dan terarah secara sistematik. Dalam dunia pendidikan konsep belajar dan pembelajaran merupakan dua kegiatan yang berproses dalam suatu sistem.

Proses belajar mengajar tidak hanya sekedar memindahkan pengetahuan dari guru ke peserta didik saja, tetapi pengetahuan itu dibentuk dan ditemukan sendiri oleh peserta didik. Guru sebagai pendidik harus menggunakan berbagai cara dan metode dalam menyampaikan materi pelajaran. Metode yang digunakan harus sesuai dengan karakteristik materi yang ada dan situasi kondisi pada saat belajar.

Dalam Kegiatan Pembelajaran, perlu dipersiapkan Sumber-sumber pembelajaran yang relevan, baik berupa Buku paket, Modul, Diktat atau Hand Out. Demikian pula dengan media dan alat pembelajaran yang harus disiapkan dalam pembelajaran seperti Lembar Kerja, Power Point, Gambar, dan sebagainya. Sumber dan media tersebut berfungsi mempermudah peserta didik dalam menggali ilmu pengetahuan dengan berbagai cara dan strategi. Dengan bantuan sumber belajar, peserta didik akan lebih mudah memahami materi dan alur yang harus dilakukan untuk mencapai ketuntasan dalam belajar.

Dalam praktek pembelajaran, masih banyak guru yang beranggapan bahwa peserta didik adalah botol kosong yang harus diisi dengan pengetahuan sampai penuh. Guru selalu menganggap bahwa peserta didik tidak tahu apa-apa dan tidak bisa mencari tahu sendiri. Pembelajaran yang seperti ini akhirnya akan melahirkan peserta didik yang tidak mampu mengembangkan kemampuan berpikirnya, sehingga tidak memiliki keberanian dalam menyampaikan pendapat, lemah dalam penalaran dan selalu tergantung pada orang lain. Akibatnya, peserta didik kurang keberanian dalam menanggapi pertanyaan guru maupun bertanya kepada guru mengenai hal-hal yang belum dimengertinya. Budaya semacam ini akan menjadi warisan yang turun temurun pada peserta didik.

Melihat gejala seperti itu, guru yang selalu berhadapan dengan peserta didik di lapangan harus benar - benar mampu untuk mengembangkan berbagai gaya dan metode atau didaktik metodik dalam proses belajar mengajar. Demikian pula dengan pengelolaan kelas yang harus dikuasai oleh seorang guru. Dalam hal ini, Dr. Indra Djati Sidi memberikan jalan keluar dengan mengubah paradikma teaching (mengajar) menjadi learning (belajar) sehingga proses pendidikan menjadi belajar bersama antara guru dengan peserta didik. Sementara Anita Lie (2002) mengemukakan bahwa yang penting dalam belajar mengajar adalah Guru sebagai pengajar tidak mendominasi kegiatan,tetapi membantu menciptakan kondisi yang kondusif serta memberikan motivasi dan bimbingan agar siswa dapat mengembangkan potensi dan kreatifitasnya melalui kegiatan belajar.

Selain itu, pembelajaran saat ini juga lebih mengarah pada metode Quantum Teaching. Menurut Bobbi De Porter (2005:7) Quantum Teanching mempunyai lima prinsip yaitu :

a. Segalanya berbicara

b. Segalanya bertujuan

c. Pengalaman sebelum pemberian nama

d. Akui setiap usaha

e. Jika layak dipelajari layak pula dirayakan .

Metode quantum teaching ini sangat bagus apabila dipahami dengan benar. Apalagi pada prinsip "akui setiap usaha". Dalam hal ini, guru harus selalu mengakui apapun pendapat dari peserta didiknya dan jangan langsung mengatakan 
jawabannya salah walaupun memang salah. Tetapi akui dulu kemampuan peserta didik tersebut dalam menjawab pertanyaan sehingga peserta didik akan bangga dan selalu ingin menjawab setiap pertanyaan yang diberikan oleh guru. Dalam setiap kegiatan belajar di kelas, peserta didik selalu merasa tidak mampu dan tidak punya keberanian dalam mengemukakan pendapatnya. Guru harus menyikapi hal ini sesuai dengan prinsip patut untuk dirayakan. Jadi dalam setiap kesempatan peserta didik terlihat aktif, maka guru harus merayakan dengan memberikan hadiah, pujian maupun ungkapan langsung, terlepas dari benar atau salah jawaban yang diberikan oleh peserta didik tersebut. Penghargaan yang diberikan oleh guru akan membuat peserta didik berlomba untuk memperoleh hadiah atau pujian dari guru. Lambat laun peserta didik akan hilang rasa takut dalan menjawab pertanyaan atau bertanya tetapi menjadi senang mengajukan pertanyaan atau menjawab pertanyaan dari guru.Karena pada hakekatnya, mengajar bukan hanya sekedar memindahkan ilmu.Menurut Furqon Hidayatulloh dalam Pumping Teacher ( 2008:47) tugas utama seorang guru adalah mengajar yang mendidik. Karena itu Guru adalah Profesi, bukan pekerjaan. Profesi memerlukan berbagai ketrampilan dan kecakapan dalam melaksanakan proses pembelajaran.

Untuk dapat melaksanakan pembelajaran seperti gambaran diatas maka solusi yang digunakan dalam penelitian ini adalah dengan menggunakan Kuis. Kuis merupakan bentuk permainan dengan mengolah pertanyaan, sehingga dapat meningkatkan keterampilan menjawab pertanyaan. Bentuk kuis dapat berupa isian singkat dan menanyakan hal-hal yang prinsip, dilakukan untuk mengetahui penguasaan pelajaran oleh siswa. Tingkat berfikir yang terlibat adalah pengetahuan dan pemahaman (Kurikulum 1994). Kuis dapat juga berupa pertanyaan ujian lisan atau tertulis secara singkat. Kuis digunakan pada acara hiburan di radio atau televisi yang berupa perlombaan adu cepat menjawab pertanyaan; cepat tepat; cerdas cermat. Di majalah dapat berupa daftar pertanyaan sederhana yang berhadiah dan kadang-kadang mengandung promosi dagang.

Maraknya kuis yang ditayangkan di televisi menjadi sebuah inspirasi bagi penulis untuk mengadakan penelitian mengenai meningkatkan prestasi belajar peserta didik melalui metode kuis. Bentuk-bentuk kuis yang pernah ditayangkan di televisi diantaranya adalah : Kuis Intermezzo, Kuis Siapa Berani, Kuis Who One To Be Millionere, Kuis Superdeal 2 Milyar, Kuis Jari Jari dan masih banyak lagi. Di antara beberapa kuis tersebut "Kuis Superdeal 2 Milyar" adalah kuis yang saat ini paling populer karena selain permainannya mudah, hadiah yang ditawarkannya pun mencengangkan para peserta. Namun, kuis yang memberi inspirasi bagi penulis untuk menerapkan metodenya dalam pembelajaran adalah "Kuis Siapa Berani".

Pembelajaran IPS perlu disampaikan dengan berbagai modifikasi dan variasi. Demikian juga dengan metode yang digunakan dalam pembelajaran IPS. Metode Tanya Jawab perlu dimodifikasi yang memerlukan sentuhan inovasi dan kreatifitas Guru. Diantaranya dengan memasukkan teknik Kuis Hom Pi Pah atau Gambreng.

Kuis yang berupa daftar pertanyaan dapat dijawab oleh peserta didik dalam setiap kelompok diskusi dengan cara melakukan Hom Pi Pah atau hom pi pa terlebih dahulu. Peserta didik yang menang dalam Hom Pi Pah lah yang berhak untuk menjawab pertanyaan dan mengumpulkan point jawaban sebagai nilai proses belajar. 
Hompimpa atau Hompimpah adalah sebuah cara untuk menentukan siapa yang menang dan kalah dengan menggunakan telapak tangan yang dilakukan oleh minimal tiga peserta (http://id.wikipedia.org/wiki/Hompimpa)

Secara bersama-sama, peserta mengucapkan kata hom-pim-pa. Ketika mengucapkan suku kata terakhir (pa), masing-masing peserta memperlihatkan salah satu telapak tangan dengan bagian dalam telapak tangan menghadap ke bawah atau ke atas. Dalam budaya Betawi, hompimpa dilakukan dengan lagu berlirik "Hompimpa alaium gambreng. Mpok Ipah pakai baju rombeng". (http://id.shvoong.com/social-sciences/education/2105614-penggunaan-metodekuis-dalam pembelajaran/\#ixzz2P67ZxKor).

Pemenang adalah peserta yang memperlihatkan telapak tangan yang berbeda dari para peserta lainnya. Ucapan Hom pi pah sudah mengalami perubahan dari kalimat pada awalnya yaitu Hongpipa. Kalimat "Hongpimpa Alaium Gambreng" Itu Bermakna "Dari Tuhan Kembali Ke Tuhan, Mari Kita Bermain !!!" berasal dari bahasa Sansekerta.

\section{METODE PENELITIAN}

Metode yang digunakan dalam penelitian ini adalah metode kualitatif bersifat deskriptif analitis. Melalui penelitian ini, peneliti berusaha memahami dan menafsirkan suatu peristiwa menurut perspektif dan hasil pengamatan, sehingga penulis mendapat gambaran secara menyeluruh mengenai masalah yang diteliti.

Pelaksanaan Penelitian Tindakan Kelas ini mengacu pada model PTK dari Kemmis dan Mc Taggart dalam Classroom Action Research (Nizar Alam Hamdani, 2008 :51) seperti gambar berikut ini :

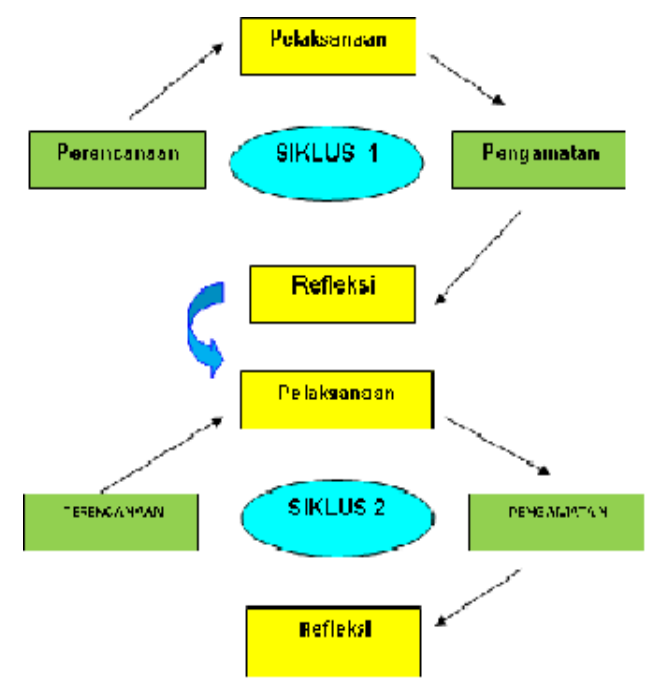

Gambar 1: Siklus Penelitian PTK

Kegiatan pengamatan dilakukan terhadap proses berupa perubahan kinerja pembelajaran dan hasil pembelajaran. Pengamatan dilakukan oleh observer. Pengamatan ini dianggap teknik paling tepat untuk mengumpulkan data tentang proses kegiatan, baik yang berupa aktifitas peserta didik, maupun kejadian kejadian selama kegiatan. Dari hasil pengamatan diperoleh data data untuk merencanakan tindak lanjut dari penelitian. 


\section{HASIL DAN PEMBAHASAN}

Dari hasil pengolahan data perolehan hasil ulangan, tingkat penguasaan peserta didik terhadap materi semakin meningkat dengan adanya perbaikan pembelajaran melalui kuis $\mathrm{Hom}$ Pi Pah pada siklus 1 dan siklus 2 .

Tabel 1. Data Perolehan Rata-rata Nilai UlanganPada Siklus 1 dan Siklus 2

\begin{tabular}{|c|c|c|c|c|c|c|c|c|}
\hline \multicolumn{5}{|c|}{ SIKLUS KE-1 } & \multicolumn{4}{|c|}{ SIKLUS KE-2 } \\
\hline Nilai & $\begin{array}{c}\text { Jml. } \\
\text { Peserta } \\
\text { didik }\end{array}$ & n.f & $\%$ & $\begin{array}{c}\text { Rata- } \\
\text { rata }\end{array}$ & $\begin{array}{c}\text { Jml. } \\
\text { Peserta } \\
\text { didik }\end{array}$ & n.f & $\%$ & $\begin{array}{r}\text { Rata- } \\
\text { rata }\end{array}$ \\
\hline 60 & 1 & 60 & 2,17 & & 0 & 0 & 0 & \\
\hline 65 & 3 & 195 & 7,08 & & 0 & 0 & 0 & \\
\hline 70 & 8 & 560 & 20,33 & & 0 & 0 & 0 & \\
\hline 75 & 15 & 1125 & 40,83 & & 7 & 525 & 17,25 & \\
\hline 80 & 7 & 560 & 20,33 & & 16 & 1280 & 42,03 & \\
\hline 85 & 3 & 255 & 9,26 & & 6 & 510 & 16,75 & \\
\hline 90 & 0 & 0 & 0 & & 7 & 630 & 20,68 & \\
\hline 95 & 0 & 0 & 0 & & 0 & 0 & 0 & \\
\hline 100 & 0 & 0 & 0 & & 1 & 100 & 3,29 & \\
\hline Jumlah & 37 & 2755 & 100 & 74,46 & 37 & 3045 & 100 & 82,29 \\
\hline
\end{tabular}

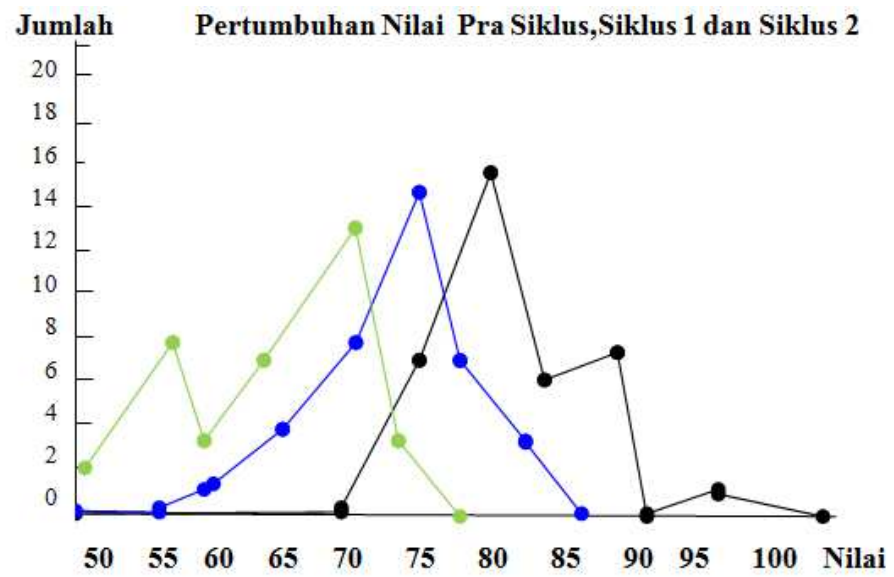

Ket :

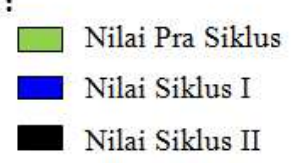

Gambar 2. Perolehan Rata-rata Nilai UlanganPada Siklus 1 dan Siklus 2

Berdasarkan hasil pengolahan data, terlihat perubahan nilai rata-rata kelas yang cukup baik pada proses pembelajaran yang telah dilaksanakan, hal ini dibuktikan dengan hasil nilai rata-rata yang semula 64,17 (pra siklus) menjadi 74,46 pada hasil pembelajaran siklus 1 dan 82,29 pada hasil pembelajaran siklus 2. Dari pengamatan terhadap aktivitas peserta didik, terjadi perubahan sikap yang bagus, peserta didik mulai berani dan aktif bertanya, berinteraksi dan bekerja sama, perhatian yang fokus serta aktif menjawab pertanyaan. Hal yang menggembirakan peneliti adalah, bahwa dengan metode kuis hom pi pah ini,peserta didik menjadi riang gembira dalam pembelajaran, tidak terlihat jenuh dan sangat antuasias untuk menjawab setiap kuis yang dibacakan oleh kelompok yang mendapat giliran tampil ke depan. 
KemajuanAktivitas belajar peserta didik selama perbaikan pembelajaran, tergambar dalam tabel di bawah ini:

Tabel 2. Aktivitas Belajar Peserta didik Pada Siklus 1 dan Siklus 2

\begin{tabular}{llll} 
NO. & YANG DIOBSERVASI & $\begin{array}{l}\text { SIKLUS 1 } \\
\text { Banyak Peserta } \\
\text { didik }\end{array}$ & $\begin{array}{l}\text { SIKLUS 2 } \\
\text { Banyak } \\
\text { didik }\end{array}$ \\
\hline 1 & Kehadiran Peserta didik & $37(100 \%)$ & $37(100 \%)$ \\
2 & Bertanya & $16(43,24 \%)$ & $37(100 \%)$ \\
3 & Menjawab Pertanyaan & $20(54,05 \%)$ & $30(81,08 \%)$ \\
4 & Memberikan Argumen & $15(40,54 \%)$ & $25(67,57 \%)$ \\
5 & Kerjasama & $30(81,08 \%)$ & $37(100 \%)$ \\
\hline
\end{tabular}

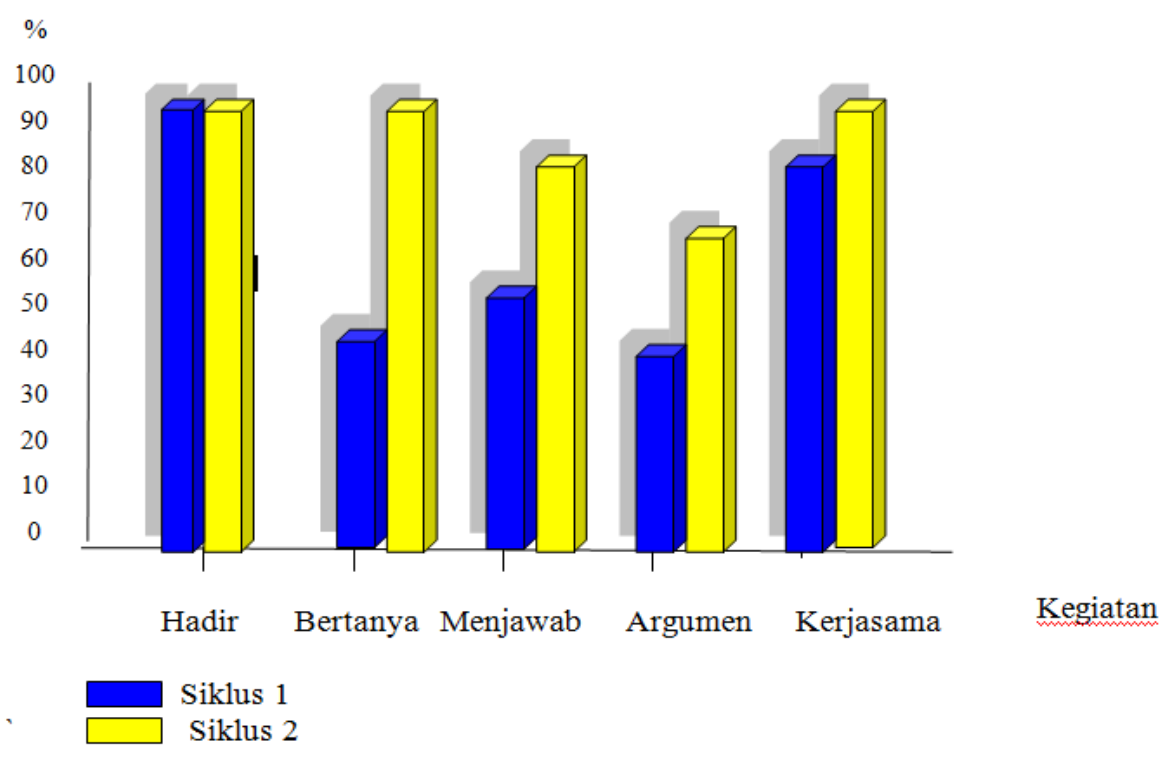

Gambar 3. Histogram Aktivitas Belajar Peserta didik Pada Siklus 1 dan Siklus 2

Tingkat penguasaan materi menunjukkan peningkatan yang signifikan. Jumlah peserta didik yang sudah mampu menguasai materi di atas KKM (75) makin bertambah, hal ini dibuktikan dari awal pengamatan sampai akhir siklus 2 terus mengalami kenaikan persentase, yaitu: pada pra siklus Peserta didik yang berhasil mencapai KKM hanya sejumlah 3 orang atau 8,33\%, siklus 1 meningkat menjadi 25 orang peserta didik atau 67,57\% dan pada siklus 2 menjadi 37 orang peserta didik atau $100 \%$. Perhatikan tabel dan grafik pertumbuhannya berikut :

Tabel 3. Penguasaan Materi / Pencapaian KKM Pra Siklus, Siklus 1 dan Siklus 2

TINGKAT PENGUASAAN MATERI DIATAS KKM (68)

\begin{tabular}{lllllll}
\hline Pra siklus & \multicolumn{3}{l}{ Siklus ke-1 } & \multicolumn{3}{l}{ Siklus ke-2 } \\
\hline $\begin{array}{l}\text { Jml peserta } \\
\text { didik }\end{array}$ & $\%$ & $\begin{array}{l}\text { Jml. } \\
\text { didik }\end{array}$ & peserta & $\%$ & $\begin{array}{l}\text { Jml. peserta } \\
\text { didik }\end{array}$ & $\%$ \\
\hline 3 & 8,33 & 25 & & 67,57 & 37 & 100 \\
\hline
\end{tabular}




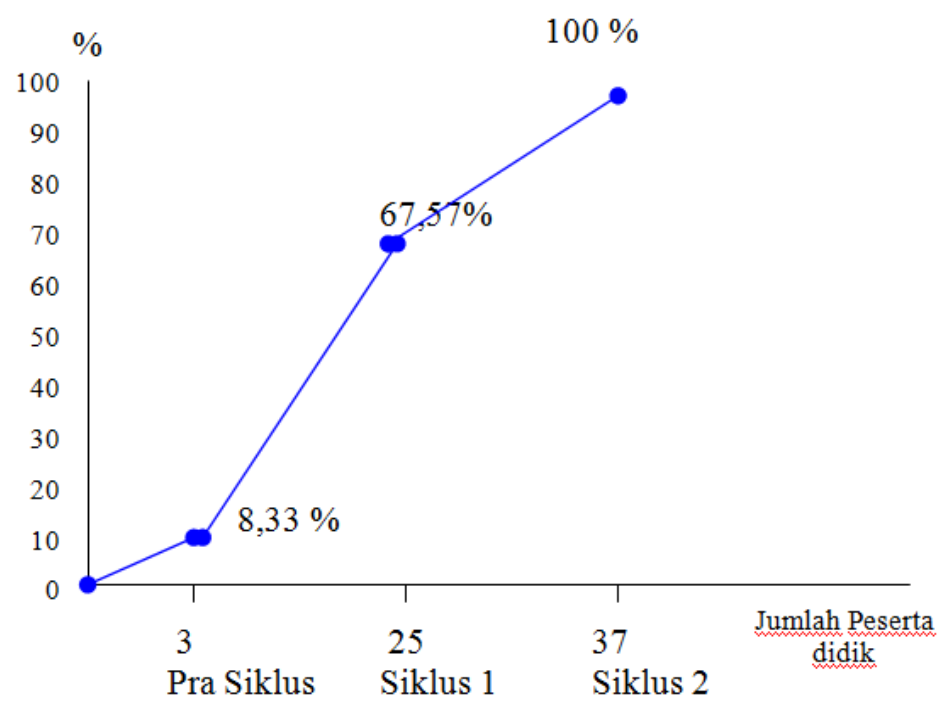

Gambar 4. Grafik Tingkat Penguasaan Materi / Pencapaian KKMPra Siklus, Siklus 1 dan Siklus 2

Dari perbaikan dalam pembelajaran dengan menggunakan metode kuis Hom Pi Pah di kelas 8.8 SMP Negeri 16 Kota Bogor, perubahan sikap maupun prestasi belajar peserta didik mengalami perkembangan yang cukup meggembirakan bagi peneliti maupun pihak sekolah. Motivasi peserta didik untuk belajar makin bergairah dan bersemangat, hal ini terjadi karena peserta didik merasa senang dalam belajar. Perasaan senang ini terlihat dari antusiasnya peserta didik dalam mengikuti proses pembelajaran dengan kuis Hom Pi Pah. Dalam pembelajaran ini, peserta didik diberi kebebasan dalam mengungkapkan argumen dan dalam mengambil kesimpulan-kesimpulan dari materi yang didiskusikan. Peserta didik sudah berani berpendapat dan aktif dalam proses pembelajaran, perubahan tersebut diantaranya, peserta didik terlihat lebih aktif bertanya, menjawab pertanyaan dalam bahasa yang mendekati kesempurnaan. Kemampuan bekerja sama juga meningkat tajam.

Proses perbaikan pembelajaran yang telah dilaksanakan menggunakan Kuis Hom Pi Pah yang tidak terlepas dari pembelajaran yang bervariasi yaitu ceramah, tanya jawab dan diskusi. Hasil pembelajaran tersebut, mampu menumbuhkan rasa percaya diri peserta didik dalam mengikuti pelajaran dikelas, sehingga komunikasi dua arah yang diharapkan terjadi dalam pembelajaran telah terbukti berjalan baik.

\section{SIMPULAN}

Penggunaan kuis Hom Pi Pah dapat mengoptimalkan pembelajaran. Kualitas perolehan nilai sebelum perbaikan (Pra Siklus), nilai rata-rata kelasnya hanya mencapai 64,17 . Setelah dilakukan perbaikan dalam dua siklus melalui diskusi dengan Lembar Kerja,nilai rata-rata kelasnya meningkat menjadi 82,29.

Penguasaan materi di atas KKM terjadi peningkatan, sebelum perbaikan pembelajaran (pra siklus) tingkat penguasaannya hanya mencapai $8,33 \%$ atau sejumlah 3 orang peserta didik, sedangkan penguasaan materi di atas KKM yang diperoleh peserta didik setelah dilakukan perbaikan di akhir siklus 2 mencapai $100 \%$. 
Research and Development Journal Of Education

Vol. 2 No. 2 April 2016

Pengelolaan Pembelajaran yang dilakukan Guru meningkat, hal ini terlihat dari skore rata-rata yang diperoleh Guru pada siklus 1 adalah 82,50\% sedangkan pada siklus kedua menjadi $98,33 \%$, ada kenaikan yang signifikan dari nilai baik menjadi amat baik.

\section{SARAN}

Dalam optimalisasi pembelajaran IPS di tingkat SLTP dapat digunakan kuis Hom Pi Pah

\section{DAFTAR PUSTAKA}

Amir Tengku Ramly \& Erlin Trisyulianti. 2008.Pumping Teacher. Memompa Teknik Pengajaran Terbaik. Bogor: Pumping Publisher

De Porter, Bobbi \& Mike Hernacki.2000. Quantum Teaching. terjemahan Alwiyah Abdurraahman. Bandung : Kaifa

Hamalik, Oemar. 1999. Kurikulum dan Pembelajaran. Bandung: Bumi Aksara.

Hamdani, Nizal Alam dan Hermana, Dody. 2008. Classroom Action Research. Bandung : Rahayasa.

Lie, Anita. 2002. Cooperative Learning, Mempraktekkan Cooperatif Learning di Ruang ruang Kelas. Jakarta: Grassindo.

Internet:

http://id.shvoong.com/social-sciences/education/2105614-penggunaan-metodekuis-dalam pembelajaran/\#ixzz2P67ZxKor http://id.wikipedia.org/wiki/Hompimpah 